\title{
Group Dynamics for Urban Farming Development in Rejowinangun, Yogyakarta City
}

\author{
Indardi ${ }^{1, *}$, Salmah Orbayinah ${ }^{2}$, and Setyo Utomo ${ }^{3}$ \\ ${ }^{1}$ Universitas Muhammadiyah Yogyakarta, Department of Agribusiness, Yogyakarta 55183, Indonesia \\ ${ }^{2}$ Universitas Muhammadiyah Yogyakarta, Department of Pharmacy, Yogyakarta 55183, Indonesia \\ ${ }^{3}$ Mercubuana University Yogyakarta, Animal Husbandry Department, Yogyakarta 55283, Indonesia
}

\begin{abstract}
This study aims to determine the group dynamics in urban farming development in Kampung Pilahan, Rejowinangun, Yogyakarta. The research method uses descriptive qualitative. Respondents consisted of leaders and administrators of urban farming groups who are truly active. Researchers conducted in-depth interviews with respondents to the chairmen and administrators of the Sinta Mina, Aisyiah, Agro 37, Agro 40 and Sledri Amigo farmer groups to explore information related to the development and group dynamics that occur in urban farming in Rejowinangun. In-depth interviews were continuously conducted, so that researchers could not find any new information (saturated information) related to urban farming. Information has been saturated when researchers have interviewed 20 respondents. Next, do data analysis, namely: compiling information in verbal tables and creating categories and compiling findings of concepts), then providing the meaning and interpretation of the relationship between the categories and concepts found. Finally a conclusion was drawn. The results showed that overall the dynamics of farmer groups were included in the "More Dynamic" category with urban farming development being included in the "More Developed" category. It is important to pay attention to the sustainability of urban farming in the future, considering that generally the members of farmer groups are old.
\end{abstract}

\section{Introduction}

Agricultural activities within the city boundaries have a long story in both developed and developing countries. Especially in developing countries these activities contribute to food security and the mitigation of malnutrition (food grown for home consumption). They generate additional income and contribute it reaction, environmental health as well as social interaction [1]. Agriculture plays an important role in economic growth, enhancing food security, poverty reduction and rural development [2]. Urban farming is one of the new cultivation methods in the urban area [3]. Urban farming function as sites of "experiential production" where farm managers stage work experiences for the volunteers and where

*Corresponding author: indardi@umy.ac.id 
visitors build new socialites, reconnect to nature, and accrue social and cultural capital in the context of a global economy that offers limited work opportunities [4]. Urban agriculture represent a industry which producing, processing and marketing vegetation fuel and product, especially in answering to daily request of consumer in urban, applying intensive production method, exploiting and recycling urban waste and resource to yield of crop [5]. In general, people think that agriculture as an activity occurs entirely in rural areas with relatively large land holdings. With increasingly limited land, narrow land farming becomes an alternative, especially in urban areas. Reluctant to talk about a partner for the beauty around the house. Urban farming has three elements: urban farming in isolation; its interface with the people and environment within which it is situated; and its contribution to the design of built form [6]. During this period, many agricultural activities were developed in urban areas. Furthermore, urban farming is oriented for various functions, including greening houses, fulfilling daily vegetable needs as well as reducing it to food security which has a broader meaning. The benefits of urban farming for public health are improving nutrition through fresh food [7].

The implementation of urban farming is also due to the economic problems of urban communities and the environment that is less beautiful. Urban farming is an activity oriented to the realization of the convenience of fulfilling daily food needs for urban communities. In addition, the presence of urban farming activities also helps fulfill and increase the area of "urban green open space". Recently, it is more prominent for the orientation of urban family economic fulfillment and nationally can help to support the food security of urban communities. The diffusion of urban farming reflects arising awareness of how food and farming can shape our cities [8]. The optimal yard ultilization would support the family's food independence a well-managed yard will provide benefits in improving family food self-sufficiency nutrition, increasing family income, and making a beautiful, picturesque, and comfortable home environment [9].

One of the urban farming activities in Yogyakarta that is quite developed and has won various achievements is urban farming in the Rejowinangun Village, Kotagede District, Yogyakarta City. Among them have won provincial and national champions in relation to the development of urban farming. The question is how to develop urban farming in Rejowinangun so that it can achieve various achievements? What are the dynamics within the group related to urban farming development in Rejowinangun? Specifically, the objectives of this research are 1) to know the urban farming development in Rejowinangun and 2) to know the group dynamics in urban farming development in Rejowinangun. This research is urgent to provide information for all parties, for the government or related agencies it can be a reference in urban farming development in other areas. For companions or community social activists it can also be an additional knowledge / reference. For the Rejowinangun community itself, this can be important information as a basis for further developing urban farming, so that it can further improve the economy of group members, more beautify the city and the increasing number of green open spaces. In addition, urban agriculture also helps to contribute to the urban greenery, healthy open space and food security [10]. Furthermore, in general, this research can be used as a basis or basis for further research. For companions or community social activists it can also be an additional knowledge / reference. For the Rejowinangun community itself, this can be important information as a basis for further developing urban farming, so that it can further improve the economy of group members, more beautify the city and the increasing number of green open spaces. Furthermore, in general, this research can be used as a basis or basis for further research. For companions or community social activists it can also be an additional knowledge / reference. For the Rejowinangun community itself, this can be important information as a basis for further developing urban farming, so that it can further improve the economy of group members, more beautify the city and the increasing number of green 
open spaces. Furthermore, in general, this research can be used as a basis or basis for further research.

\subsection{Urban Farming}

Urban farming is citizens' response to the ecological crisis in urban area, this program is a counterweight to the urban development which is dominated by physical development without taking ecological equity into account resulting environmental degradation [11]. Urban farming discourse by the Indonesia Berkebun movement is closely related to the global discourse on urban farming that is associated with economic, social and environmental potential [12]. Urban farming is described as the activity of cultivating, processing and distributing food and non-food crops, trees and livestock Mougeot in [13]. The commodities cultivated in urban farming are vegetables, fruits, ornamental plants, forest plants, large andsmall poultry and ruminants, and fish BPS 2013 in [14]. The role of urban farming in optimizing land use and utilizing free time for activities in urban farming will bring them closer to access to food and maintain environmental sustainability with green open spaces. There are also many now-acknowledged ecological benefits of reducing greenhouse gas emissions (e.g., lower food transport distance), resource consumption, and municipal organic waste, and in raising biodiversity and attenuating urban heat island effects [15]. in a study in Nigeria Urban Farming is the main thing in helping to control erosion in cities [16]. Therefore, the role of community is very crucial in the implementation of urban farming activities within urbanized areas as the demand for green development increases [17]. The urban farmer, like any other farmer, will typically produce to satisfy household food needs or make profit or both [18]. Urban farming is one of the key components of a sustainable community foodsystem development and if properly designed it will be able to alleviate the problem of food insecurity. many problems in the urban environment, it is important for urban people to create a city environment resilient, sustainable and a happy place to live [19]. In this research, urban farming is not seen as an industry but as cultivation practices that occur in urban areas [20].

\subsection{Urban farming Development}

Urban farming is a broad term that describes food cultivation and animal husbandry on urban and suburban land [21]. Urban farming is seen as a sustainable practice with the social, economic and urban environment benefits [22]. Urban agriculture has a positive impact on people's livelihood in urban areas, both in social, economic, and environmental perspectives [10]. Urban farming development management concerns how to manage the planned development activities in accordance with the desired at various levels of management (according to their respective duties, authorities and responsibilities) in an urban farming development group. In order to ensure the achievement of group goals, the development must be able to show how tactical operations must be done. An approach to development can vary according to situations and conditions. Urban farming is the practice of community gardening as an organizational strategy, a complete approach to supporting and engaging individuals and neighborhoods, advancing economic development through food production, improving neighborhood safety through combating blight, and exposing youth to intergenerational interactions and encouraging self-reliance has been a trend [23]. Urban farming development should be understood, have the same perception and become a joint commitment by all group members, both institutionally and individually. Only then will the group's goals be easier to achieve. 


\subsection{Group Dynamics}

Dynamics is something that implies strength, always moves, develops and can adapt itself adequately to circumstances. Dynamics can also mean the existence of interaction and interdependence between group members and the group as a whole. Groups that can maintain their enthusiasm or can create (group spirit) is the reason for the creation of interaction and interdependence [24]. [25] States that group dynamics is a process method that aims to increase the value of group collaboration. As a process method, group dynamics seeks to build and grow a group that originally consists of a group of individuals who do not know each other to become a group unit with mutually agreed goals, norms and means of achievement. Even from the results of research by [26] on "the multicultural dynamics of the people of the city of Surabaya", the villages in Surabaya have been living in multiculturalism, there is no discrimination related to ethnicity, religion, and various levels of welfare can live in harmony and side by side. One of the reasons is because Surabaya has developed infrastructure that supports various urban farming activities. Namely, various togetherness activities in the community, such as city parks. one of the reasons is because Surabaya has developed infrastructure that supports various urban farming activities. Namely, various togetherness activities in the community, such as city parks. One of the reasons is because Surabaya has developed infrastructure that supports various urban farming activities. Namely, various togetherness activities in the community, such as city parks. Dynamic of urban farming brings a significance which contributed by the fast growth of urban population [27]. Group dynamics is a study of the forces that exist both within and outside the group environment that can determine and influence the behavior of group members to carry out or carry out activities or things so that the goals that have been set are achieved. Examining group dynamics means also examining the forces that emerge from various sources within the group and outside the group and try to find fibers studying the interactions of group members inside and doing problem solving.

The research, entitled Group Dynamics in Urban farming Development, refers to the policies of the UMY Agribusiness Study Program, adjusted to the formulation of superior research topics for the Agribusiness Study Program with the strategic issue of "sustainable agribusiness" in solving the problem of "profitable and sustainable agribusiness development (economy and ecology / greening / environment / beautiful) ". In more detail related to the leading research topics of Agribusiness study program, please see the following table along with the fishbone diagram.

\section{Method}

The people of Yogyakarta City have carried out activities urban farming over the last few decades to use their homes as yards used for planting [28]. This research uses a qualitative paradigm, with a qualitative descriptive research method. Qualitative research is a research method based on the philosophy of post positivism, used to examine the condition of a natural object called the researcher as a key instrument, the sampling of data sources is done purposively, the collection technique is by triangulation, the data analysis is inductive /qualitative, and the results of the research, qualitative emphasizes meaning more than generalization [29].

The research location is in the area of Rejowinangun Village, Kotagede Yogyakarta. Technique of taking information by in-depth interview (in-depth interview). The research begins with an FGD (Initial FGD) with the community in the research location. FGD is intended to socialize the existence of this research, the purpose and importance of the research, how respondents should provide descriptions or explanations according to the 
expectations of the research objectives, including the benefits of research results, especially for urban farming groups. In this InitialFGD, the researchers also found out who were the respondents or informants from each of the urban farming groups in Rejowinangun who were believed to really know about urban farming. Selected respondents may consist of group joint leaders, former joint group leaders, agricultural extension workers, village heads, initiators, opinion leaders, group leaders, group administrators, former group administrators, and members who are truly active. With the Agricultural advisory services, also called extension services, are a critical element of strategies for improving smallholder farmer development, agricultural productivity and food security [30]. The next stage, the researcher conducted in-depth interviews with respondents in each group in 15 urban farming groups in Rejowinangun Village, related to perceptions, development strategies and group dynamics related to urban farming. It is estimated that at least 20 respondents actually know. In-depth interviews were continuously conducted, so that researchers could not find any new information (saturated information) related to urban farming. It is estimated that the information becomes saturated until 45 respondents were interviewed. In order to avoid possible loss of information, a voice recorder is needed during the interview. The next stage is to process data, namely: typing records, structuring information, reducing data / information. Furthermore, the triangulation process was carried out by carrying out the final FGD activity. The Final FGD was conducted to ensure that all important information collected was correct and factual (there were no mistakes). Next, do data analysis, namely: compiling information in verbal tables and creating categories and compiling findings of concepts), then providing the meaning and interpretation of the relationship between the categories and concepts found. Finally a conclusion was drawn to increase data sakhehan.

\section{Results}

\subsection{Urban farming Development}

The urban farming development in question is the development of activities in vegetable farming is being pursued by members and administrators of the urban farming group in Rejowinangun, which is supported by the government (Dinas Pertanian) in Yogyakarta city. In order to create food security and food self-sufficiency, The Ministry of Agriculture, in developing programs with farmers, has tried to implement the concept of empowerment [30]. Measurement of the level of development is grouped into 3 categories, namely: a) Less Developed, b) Moderately Developed and c) More Developed. The development of urban farming farmer groups in Rejowinangun, Yogyakarta City is relatively diverse in its development. The development of urban farming farmer groups includes indicators of the development process, types of activities, methods of development, as well as barriers and ways to overcome them. The urban farming farmer group in Rejowinangun has had relatively diverse developments. There is diversity both for the development of each indicator within a farmer group and the diversity of urban farming development between one farmer group and another urban farming farmer group. So that the development conditions of each farmer group also vary. The details can be seen in table 1 . 
Table 1. Description of Development and Category of Urban Farming Development in Rejowinangun Yogyakarta City

\begin{tabular}{|c|c|c|c|c|}
\hline $\begin{array}{c}\text { Group } \\
\text { name }\end{array}$ & Indicator & Development Description & $\begin{array}{c}\text { Indicator } \\
\text { Development } \\
\text { Category }\end{array}$ & $\begin{array}{c}\text { Group } \\
\text { Development } \\
\text { Category }\end{array}$ \\
\hline \multirow[t]{4}{*}{\begin{tabular}{|l|} 
Shinta \\
Mina
\end{tabular}} & $\begin{array}{l}\text { Development } \\
\text { Process }\end{array}$ & $\begin{array}{l}\text { Shinta Mina's group was founded in } 1976, \\
\text { then urban farming emerged in } 2013, \text { the } \\
\text { community responded that there were pros } \\
\text { and cons to urban farming. The initial idea } \\
\text { was conveyed by the government through } \\
\text { the members of the Retno Makmur group. } \\
\text { The development process continues. } \\
\text { Initially the orientation / initial goal was for } \\
\text { greening, then, among other things, it was } \\
\text { also aimed at conserving food, developing } \\
\text { for vegetable alms from fellowneighbors, } \\
\text { and so on. The development of this } \\
\text { orientation is truly manifested in the } \\
\text { activities of group members. }\end{array}$ & $\begin{array}{l}\text { More } \\
\text { Developed }\end{array}$ & \multirow[t]{4}{*}{$\begin{array}{l}\text { More } \\
\text { Developed }\end{array}$} \\
\hline & $\begin{array}{l}\text { Type of } \\
\text { activity }\end{array}$ & $\begin{array}{l}\text { The activities of urban farming farmer } \\
\text { groups begin with the intention of members } \\
\text { and administrators to cultivate crops and the } \\
\text { existence of government support. Initial } \\
\text { activity is just cultivation, then consumed } \\
\text { alone. It grew until something was sold to } \\
\text { become a tourist village and the economy of } \\
\text { the people increased. The most prominent } \\
\text { activities are when preparing for the race } \\
\text { and } \\
\text { entering the race, as well as making picket } \\
\text { schedules for maintenance. }\end{array}$ & $\begin{array}{l}\text { More } \\
\text { Developing }\end{array}$ & \\
\hline & $\begin{array}{l}\text { Way of } \\
\text { Development }\end{array}$ & $\begin{array}{l}\text { The method of development is by } \\
\text { distributing seeds and planting media under } \\
\text { the direction of the chairman and elders. } \\
\text { Continue to carry out planting and } \\
\text { maintenance on a scheduled basis, } \\
\text { community service and mutual tolerance } \\
\text { between members. There is no specific way } \\
\text { of developing urban farming. Only when } \\
\text { facing a race, the members work harder so } \\
\text { they often win races. Now it is } \\
\text { forbidden to take part in any more } \\
\text { competitions }\end{array}$ & $\begin{array}{l}\text { More } \\
\text { Developed }\end{array}$ & \\
\hline & $\begin{array}{l}\text { Obstacles } \\
\text { andHow to } \\
\text { Overcome }\end{array}$ & $\begin{array}{l}\text { The way to overcome barriers to pests is } \\
\text { using organic (natural) pesticides, a difficult } \\
\text { growing medium, buying with group cash. } \\
\text { A difficult obstacle to overcome is } \\
\text { developing member awareness in regular } \\
\text { meetings. The reasonis that there are } \\
\text { different activities for each member and the } \\
\text { uncertain weather. Barriers can be } \\
\text { overcome effectively, namely the presence } \\
\text { of pests that are overcome with natural } \\
\text { pesticides and Planting media that are } \\
\text { difficult to find bybuying with cash. }\end{array}$ & $\begin{array}{l}\text { More } \\
\text { Developed }\end{array}$ & \\
\hline
\end{tabular}




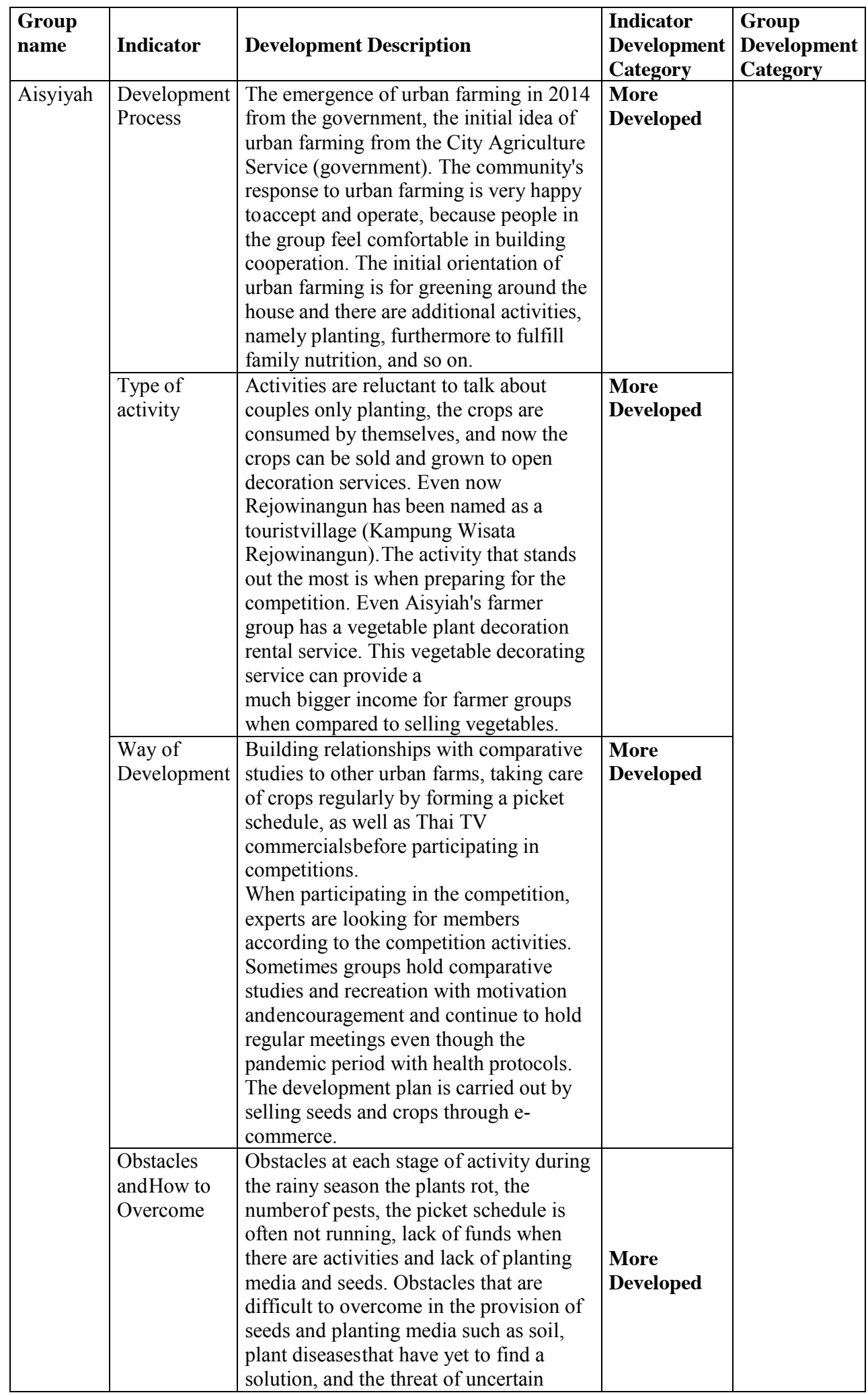




\begin{tabular}{|c|c|c|c|c|}
\hline & & $\begin{array}{l}\text { weather. The obstacle to be overcome for } \\
\text { pests is spraying with homemade } \\
\text { pesticides from detergent drugs } \\
\text { (squeezed tailings), the missing funds } \\
\text { were covered by group cash. } \\
\text { Barriers that are handled effectively, } \\
\text { suchas pests being sprayed with } \\
\text { environmentally friendly pesticides, lack } \\
\text { of funds can be covered using group } \\
\text { cash,and schedule caring for neglected } \\
\text { plants so that fellow members tolerate } \\
\text { and remind each other. }\end{array}$ & & \\
\hline $\begin{array}{l}\text { Group } \\
\text { name }\end{array}$ & Indicator & Development Description & \begin{tabular}{|l|} 
Indicator \\
Development \\
Category
\end{tabular} & \begin{tabular}{|l|} 
Group \\
Development \\
Category
\end{tabular} \\
\hline \multirow[t]{3}{*}{ Agro 37} & $\begin{array}{l}\text { Development } \\
\text { Process }\end{array}$ & $\begin{array}{l}\text { The beginning of the emergence of urban } \\
\text { farming was a policy of planting a } \\
\text { minimum of } 5 \text { polybags per family. The } \\
\text { initial idea of urban farming came from } \\
\text { the activists and supported by community } \\
\text { leaders (lurah). Reluctant to talk about the } \\
\text { pairs of responses from the community, } \\
\text { many people refused (contra), after } \\
\text { seeingthe results the community became } \\
\text { interested, realized the benefits and } \\
\text { agreed. The initial purpose of urban } \\
\text { farming was to get along well, then to } \\
\text { develop it to utilize the yard, then it was } \\
\text { also intended to fulfill family nutrition, } \\
\text { then also for greening the environment, } \\
\text { there was even awareness of being able to } \\
\text { educate character, then the intention was } \\
\text { to give oxygen alms. }\end{array}$ & \begin{tabular}{|l|} 
More \\
Developed
\end{tabular} & \multirow[t]{3}{*}{$\begin{array}{l}\text { More } \\
\text { Developed }\end{array}$} \\
\hline & $\begin{array}{l}\text { Type of } \\
\text { activity }\end{array}$ & $\begin{array}{l}\text { Reluctant to talk about couples only } \\
\text { growing vegetables in pots. Then also } \\
\text { plant in polybags. Reluctant to talk about } \\
\text { planting partners only in the yard or } \\
\text { terrace of the house, then planting } \\
\text { develops in the alleys (vegetable alley } \\
\text { program). They even plant in empty } \\
\text { yards, and do vertical planting on fences } \\
\text { or houses (green village program). Urban } \\
\text { farming activities in RT } 37 \text { are } \\
\text { increasingly developing, so that they } \\
\text { become a pioneer as a tourist village for } \\
\text { Rejowinangun. Activities that stand out } \\
\text { when preparing for a competition and } \\
\text { when participating in a competition. Agro } \\
37 \text { farmer group pioneered defending the } \\
\text { title of tourism village by greening the } \\
\text { city, as well as an active role in } \\
\text { participating in competitions so that they } \\
\text { have many relationships. }\end{array}$ & \begin{tabular}{|l|} 
More \\
Developed
\end{tabular} & \\
\hline & \begin{tabular}{|l|} 
Way of \\
Development
\end{tabular} & $\begin{array}{l}\text { Maintain and continue the status of the } \\
\text { Tourism Village by building a spirit of } \\
\text { loving plants. With the existence of a }\end{array}$ & $\begin{array}{l}\text { More } \\
\text { Developed }\end{array}$ & \\
\hline
\end{tabular}




\begin{tabular}{|c|c|c|c|c|}
\hline & & $\begin{array}{l}\text { comparative study to other agricultural } \\
\text { places and an active role in participating } \\
\text { in competitions. Doing a planting routine } \\
\text { because it has become a tourist village. } \\
\text { The plan for the future is to supply } \\
\text { vegetables to the supermarket and the } \\
\text { surrounding Pecel Lele. This program has } \\
\text { not been implemented, because there is a } \\
\text { Covid-19 pandemic. }\end{array}$ & & \\
\hline & $\begin{array}{l}\text { Obstacles } \\
\text { andHow to } \\
\text { Overcome }\end{array}$ & $\begin{array}{l}\text { Obstacles for each activity stage include } \\
\text { layout and plant space, for example } \\
\text { limited exposure, limited budget, limited } \\
\text { planting media, for example soil, poultry } \\
\text { damage crops, lack of motivation, } \\
\text { presence of pests, and decreased } \\
\text { cohesiveness. Barriers that are difficult to } \\
\text { overcome are scarcity of planting media } \\
\text { such as soil. Difficult to believe in the } \\
\text { presence of buyers (have been deceived } \\
\text { by buyers). New management structures, } \\
\text { new community leaders must be new } \\
\text { policies, and plant diseases for which } \\
\text { there is no solution. Barriers that can be } \\
\text { overcome, such as planting according to } \\
\text { the season, utilizing government } \\
\text { assistance, the limited budget is covered } \\
\text { using group cash, establishing policies for } \\
\text { poultry owners, and spraying pests with } \\
\text { organic (natural) pesticides. Barriers are } \\
\text { overcome effectively such as layout and } \\
\text { space by adjusting the weather. }\end{array}$ & $\begin{array}{l}\text { More } \\
\text { Developed }\end{array}$ & \\
\hline $\begin{array}{l}\text { Group } \\
\text { name }\end{array}$ & Indicator & Development Description & \begin{tabular}{|c|} 
Indicator \\
Development \\
Category \\
\end{tabular} & \begin{tabular}{|c|} 
Group \\
Development \\
Category \\
\end{tabular} \\
\hline Agro 40 & $\begin{array}{l}\text { Development } \\
\text { Process }\end{array}$ & $\begin{array}{l}\text { At the beginning of the emergence of } \\
\text { urban farming, there was a service } \\
\text { program from UGM lecturers who } \\
\text { provided counseling on how to plant } \\
\text { usingused bottles, After that in } 2018 \\
\text { received assistance from the Agriculture } \\
\text { Office. The initial idea of urban farming } \\
\text { was through Mrs. Sri Wahyuni as the } \\
\text { initiatorand activist of the group. The } \\
\text { community's response is positive towards } \\
\text { urban farming because it is beneficial for } \\
\text { the environment. The initial goal was to } \\
\text { green the village by planting. }\end{array}$ & $\begin{array}{l}\text { Quite } \\
\text { Developed }\end{array}$ & $\begin{array}{l}\text { Quite } \\
\text { Developed }\end{array}$ \\
\hline & $\begin{array}{l}\text { Type of } \\
\text { activity }\end{array}$ & $\begin{array}{l}\text { The activity of group members is by } \\
\text { planting vegetables in pots on the terrace } \\
\text { of each member's house according to } \\
\text { theirfree time. Many members do not } \\
\text { grow vegetables (more than } 60 \% \text { ). There } \\
\text { is one gang that has planted vegetables } \\
\text { vertically. Regular meetings do not } \\
\text { always exist, have had comparative } \\
\text { studies, andparticipated in exhibitions. }\end{array}$ & \begin{tabular}{|l} 
Less \\
Developed
\end{tabular} & \\
\hline
\end{tabular}




\begin{tabular}{|c|c|c|c|c|}
\hline & $\begin{array}{l}\text { Way of } \\
\text { Development }\end{array}$ & $\begin{array}{l}\text { Of course, following the Instructor's } \\
\text { direction by prioritizing planting and } \\
\text { trying to regularly do planting so that the } \\
\text { planting media is not empty. The hope is } \\
\text { that you can be active in association } \\
\text { activities so you can get broad } \\
\text { relationships, remind each other and } \\
\text { tolerate fellow group members. He also } \\
\text { hopes to plant more so that more profit, } \\
\text { not only planting but also caring. The } \\
\text { wayof development in the future should } \\
\text { prioritize harmonious harmony between } \\
\text { members and administrators, and do good } \\
\text { planting to make it look greener and } \\
\text { tidier.Active members continue to carry } \\
\text { out activities so that the group does not } \\
\text { die. The limited funds can be covered by } \\
\text { duesas much as possible. }\end{array}$ & \begin{tabular}{|l} 
Quite \\
Developed
\end{tabular} & \\
\hline & $\begin{array}{l}\text { Obstacles } \\
\text { andHow to } \\
\text { Overcome }\end{array}$ & $\begin{array}{l}\text { Barriers to group activity are the quality } \\
\text { ofhuman resources that is not supportive } \\
\text { andvery few, the presence of pests and a } \\
\text { less active workforce. Limited funds to } \\
\text { support activities. However, there are } \\
\text { obstacles that cannot be overcome, such } \\
\text { asdiseases in eggplant and chili plants, } \\
\text { and members who are not aware of their } \\
\text { respective roles. Overcoming pests by } \\
\text { spraying natural pesticides on the affected } \\
\text { plants. The limited funds are covered by } \\
\text { dues as minimal as each meeting. }\end{array}$ & \begin{tabular}{|l|} 
Quite \\
Developed
\end{tabular} & \\
\hline $\begin{array}{l}\text { Group } \\
\text { name }\end{array}$ & Indicator & Development Description & \begin{tabular}{|c|} 
Indicator \\
Development \\
Category \\
\end{tabular} & \begin{tabular}{|c|} 
Group \\
Development \\
Category \\
\end{tabular} \\
\hline \multirow[t]{2}{*}{$\begin{array}{l}\text { Seledri } \\
\text { Amigo }\end{array}$} & $\begin{array}{l}\text { Development } \\
\text { Process }\end{array}$ & $\begin{array}{l}\text { The beginning of the emergence of urban } \\
\text { farming, residents have not accepted it, } \\
\text { after being aware of the slum } \\
\text { environmentand finally the residents } \\
\text { became aware and started doing urban } \\
\text { farming activities. The initial idea of } \\
\text { urban farming was through Pak Sony and } \\
\text { Pak Wanto as group movers. The } \\
\text { community response was very good and } \\
\text { agreed with the urban farming activity. } \\
\text { The initial objective of urban farming } \\
\text { was to green the environment, } \\
\text { furthermore to make it look clean and } \\
\text { beautiful to look at, besides that the } \\
\text { results can be used for daily needs. }\end{array}$ & $\begin{array}{l}\text { More } \\
\text { Developed }\end{array}$ & \multirow[t]{2}{*}{$\begin{array}{l}\text { More } \\
\text { Developed }\end{array}$} \\
\hline & $\begin{array}{l}\text { Type of } \\
\text { activity }\end{array}$ & $\begin{array}{l}\text { The development of urban farming } \\
\text { activities is fluctuating. Sometimes } \\
\text { excited, sometimes lacking enthusiasm. } \\
\text { Members plant vegetables in pots and } \\
\text { polybags. In some places, vegetables are } \\
\text { planted vertically. The activities that } \\
\text { standout are the planting together, the } \\
\text { routine meetings every } 3 \text { months during }\end{array}$ & \begin{tabular}{|l|} 
Quite \\
Developed
\end{tabular} & \\
\hline
\end{tabular}




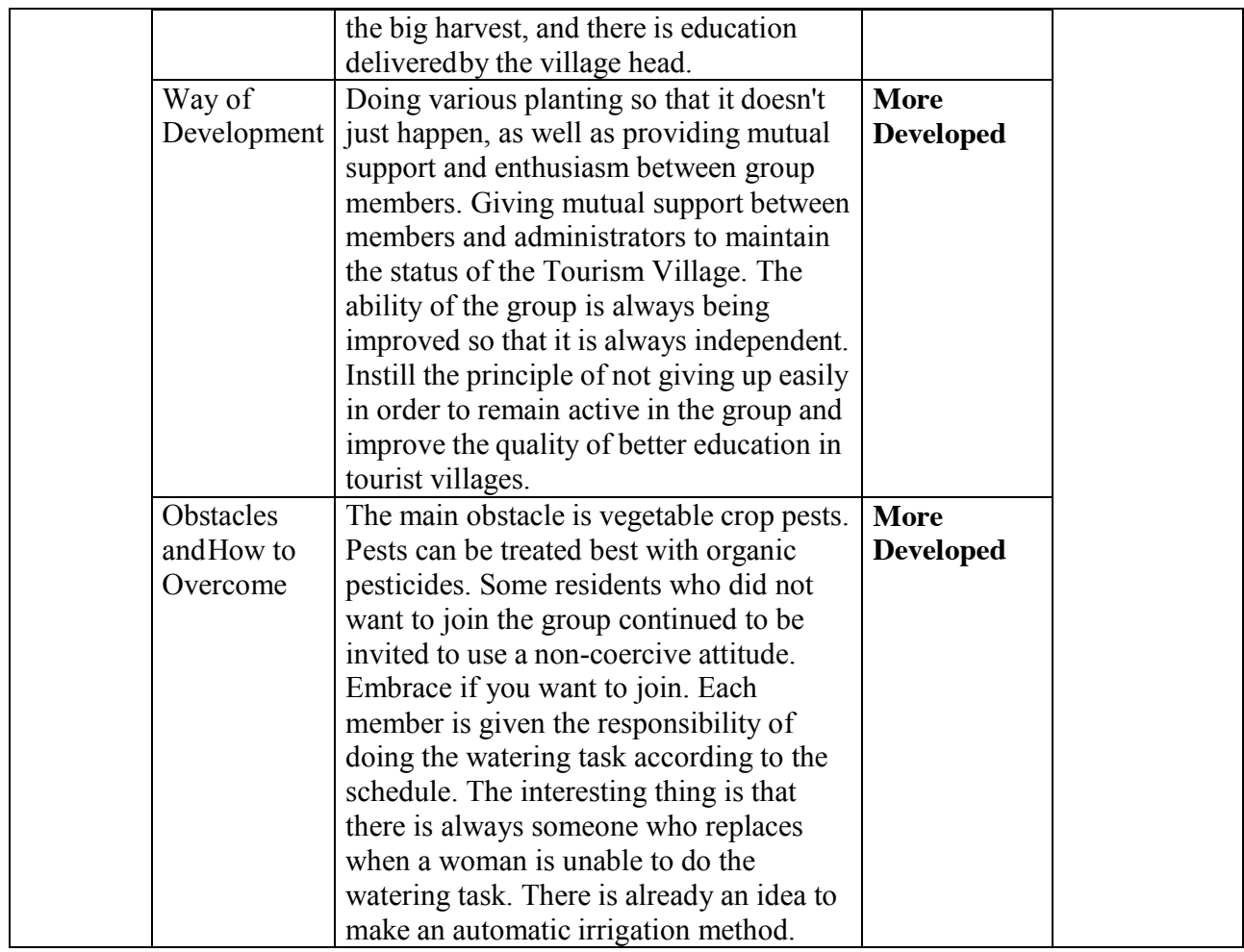

KWT Sinta Mina RT 37 RW 12 consists of 25 people, on average they are over 50 years old and on average they have also retired from office work. Mrs. Mujinah as the head of KWT Sinta Mina is 69 years old. Production of urban farming plants in the form of pak coi vegetables, mustard greens, chilies, tomatoes, bell peppers, eggplants, etc. Generally, production is still on a small scale and only consumed by the members themselves. Members who are interested in consuming vegetables then buy the vegetables and the money from the sale is put into the group treasury. Plants produced by KWT Sinta Mina in urban farming are more oriented for tourism purposes and for participating in competitions. The crops sold to visitors have a much higher price than the crops sold by KWT members Sinta Mina. Because production is still very limited, relatively no waste is found.

Shinta Mina. In the indicators of the development process of Urban Farming, Shinta Mina's group is included in the More Developed category, this is influenced by the oldest age group since 1976 compared to other groups, because Shinta Mina's group has experienced many developments in terms of management, technology utilization, number of members, and others. One of them is the urban farming technology which emerged in 2013, so that the pros and cons of the community's response to urban farming emerged. The initial idea of urban farming technology was first initiated by the government through the fathers of the Retno Makmur group, where the Retno Makmur group consists of all fathers and focuses on food crops.

Types of Urban Farming activities fall into the more developed category, seen from the most prominent activities occurring when preparing for competitions, so that all group members are involved in them. Situation during race preparation, the ownership of household assets in group becomes important. Household assets play an important role in determining participation in marketing activities and the profitability of urban farming [31]. Social assets are one of the key elements in reducing the incidence of poverty as it can affect the income level of an individual or household in a country [32]. Reluctant to talk 
about this pair of agricultural urban activities, just farming and consuming it themselves, so that it grows from vegetable crops that can be sold until finally getting the title Rejowinangun Tourism Village, and can improve the economy of the surrounding community. This study in Malaysia revealed that urban farming had benefited the urban community as well as create awareness through the supply of nutritious vegetables to households, improve the appearance of the housing compounds and reduced household expenses [33]. The development method is carried out step by step, namely the group buys seed tapes and planting media to each family with the direction of the group leader, each family is required to invest maintenance funds on a scheduled basis, besides that there is a group principle of mutual tolerance between members so that the group remains compact.

The obstacles faced by the group also varied, such as pest attacks, growing media that were difficult to find, to fewer human resources and less active members in the group. The obstacles that can be faced, such as pests, are overcome by spraying organic (natural) pesticides, the difficult planting medium was bought using group cash. There are also obstacles that cannot be overcome such as plant diseases because members only carry out the planting change process, members who are less active because these members have different activities, besides that the weather is uncertain because it is beyond our will, so that obstacle indicators can be found and how to solve it is in the More Developed category.

It can be concluded that the activity indicators carried out by Shinta Mina's group are in the More Developed category, because most of the developments made by Shinta Mina's grouphave been well realized.

KWT Aisyiyah RT 37 RW 12 consists of 23 housewives, generally also consists of mothers who have retired from office work, Ibu Zuriyah as the head of the 66-year-old group. The amount of production is also only for the vegetable needs of its members by buying, the money from the sale is included in the group treasury. The vegetable plants that are cultivated are Pak choi, chilies, mustard greens, eggplant, kale and flower plants, especially orchids and fruit plants in pots such as avocado, manganese, guava, oranges. There is also a photo spot for visitors. Aisyiyah gets funds aside from selling vegetables from members as well as selling vegetables from visitors and there is an entry for visitors who take photos in photo spots, then there is additional funds from each competition. KWT Aisyiyah not yet. KWT Aisyiyah also has not produced waste that can be used for organic fertilizer.

KWT Aisyiyah. In the indicators of the development process of Urban Farming, the KWT Aisyiyah group is included in the More Developed category, the beginning of the emergence of Urban Farming in 2014 from the government with the initiator through the Agriculture Service. It was one year different from Shinta Mina's group, which appeared earlier because at that time the group that had been active previously was Shinta Mina. The response from the community and KWT Aisyiyah to the existence of Urban Farming is very open by doing it happily because people in the group feel comfortable in building cooperation. The initial goal of KWT Aisyiyah was to have urban farming, namely for reforestation, fulfilling family nutrition, members having planting activities. In the future, of course, they want to be more developed, more efficient, and have a function as tourism. Urban farming emphasizes the efficient and practical agricultural production and simultaneously fulfils the landscape needs, attraction features, and design for tourism absorption [34].

KWT Aisyiyah's initial type of activity was just planting, the harvest was consumed by herself, and then growing from the harvest that could be sold continued to grow until she opened a vegetable plant decoration service until the village got the title Rejowinangun Tourism Village. The most prominent activity when preparing for the competition, even KWT Aisyiyah has Vegetable Plant Decoration services. This Vegetable Plant Decoration service can provide much greater income for farmer groups when compared to selling 
vegetables. This means that Aisyiyah's KWT activity type indicator is in the More Developed category.

As for the method of development carried out by KWT Aisyiyah, building relationships with comparative studies to other urban farms, carrying out routine plant maintenance by forming a picket schedule, as well as Thailand TV commercial advertisements before participating in the competition by looking for members who are experts in the field of competition activities, Sometimes the group holds recreation with motivation and encouragement and continues to hold regular meetings even during the pandemic by prioritizing health protocols. So that the indicator of Aisyiyah's KWT Development Method is in the More Developed category.

KWT Aisyiyah has certain obstacles such as entering the rainy season, the plants rot, the number of pests, the picket schedule often doesn't work, lack of funds when there are activities and lack of planting media and seeds. Barriers that can be overcome, such as pests, are sprayed using homemade pesticides from detergent drugs (squeezed tailings), the missing funds were covered with group cash. The above barriers are effectively pests that previously experienced a lot of reduction after spraying with environmentally friendly pesticides, the plant maintenance schedule always has members who remind and tolerate replacing it if someone is unable to. There are obstacles that are difficult to overcome when planting media that is difficult to obtain, namely soil, plant diseases for which there is no solution, and the threat of erratic weather. So that it makes an indicator of obstacles and how to overcome them. KWT Aisyiyah is in the More Developed category.

It can be concluded that the group development indicators of the activities carried out by Aisyiyah's KWT group are in the More Developed category, because most of the development of activities carried out by Aisyiyah's KWT group has been going well.

Agro 37 consists of all residents of RT 37 RW 12, totaling 39 families, agro group 37 has members consisting of men and women from RT 37 in Pilahan village, Rejowinangun Village. The head of the 37 agro group is a man named Pak Darma who is 56 years old. The age of members of the 37 agro group is relatively diverse, the youngest is 27 years old and the oldest is 65 years old. The group treasurer named Mas Adit is 27 years old. Plants cultivated also include vegetable crops such as mustard greens, pak choi, chilies, loncang, lettuce. Fruit plants such as guava, manga, avocado, star fruit, etc. Besides planting urban farming plants, he also sells planting media, such as plastic mulch, polybags, planter bags, wall bags, plastic tarpaulins for fish cultivation. Agro 37 has supplied vegetables from urban farming to several supermarkets, although it has not been sustainable. After the pandemic, sales to supermarkets have stopped. There are future thoughts to cooperate with Muhammadiyah in marketing vegetable products. The head of the 37 agro group has started to produce organic pesticides, besides being used for organic pesticide groups, they are also sold outside the group. In trying organic pesticides, it is categorized as a pioneering business, because at the time the research was carried out this business was just starting. The 37 agro group also often wins competitions related to urban farming.

Agro 37. In the indicators of the development process of Urban Farming, the Agro 37 group is included in the More Developed category, this is seen from the beginning of the emergence of urban farming through the existence of a community agreement supported by community leaders, namely the Head of the Village, with a policy that every family is required to plant a minimum of 5 polybags of vegetable crops. With the initiator of urban farming from the initiator Mr. Darma and community leaders Bu Lurah at that time. At the beginning of the community's response to urban farming, there were many who refused (contra), after seeing the results the community became interested, realized the benefits obtained and began to agree (pro). The initial goal of urban farming of the Agro 37 group started from getting along well with fellow members and administrators and utilizing the house yard. Then develop in meeting the nutritional needs of the family. Social benefits of 
urban farming included more interaction with neighbors, improved social status and social network and relieved stress from monotonous office work [35].

Types of activities carried out by the Agro 37 group were reluctant to talk about couples only planting vegetables in used pots or bottles, then planting them in polybags was done only in the yard or the terrace of the house. Then it developed by utilizing the walls of the village alleys as well as vertical vegetable planting known as (Lorong Sayur Program), even planting in empty yards and utilizing house fences or walls known as (Green Village Program). Urban farming activities at RT 37 are growing so that they have become a pioneer as a Rejowinangun tourism village. The activities that stood out at that time were while preparing for the competition and the time to enter the competition. The Agro 37 group pioneered defending the title of Kampung Wisata by greening the city, and taking an active role in participating in competitions so that they have many relationships. Activities urban farmers, unlike other urban agricultural projects, farm to make a living. They raise produce and grow ornamentals to sell in their community, while building food literacy and comfort for customers and the surrounding community [36].

The method of development carried out by the 37 Agro Group is to maintain and continue the status of the Tourism Village by building a spirit of loving plants. There is a comparative technical study to other urban farming places and an active role in participating in the competition. Doing routine planting because it has become a Tourism Village. The future development plan will supply vegetables to supermarkets and catfish pecel around. So that makes the indicator of Agro Group Development Method 37 in the More Developed category.

The obstacles faced by the Agro 37 group include layout and plant space, for example limited exposure, limited budget, limited planting media such as soil, poultry damage to crops, lack of motivation, presence of pests, and decreased compactness. Barriers that can be overcome, such as planting according to the season, utilizing government assistance, the limited budget is covered using group cash, establishing policies for poultry owners, and spraying pests with organic (natural) pesticides. Barriers are overcome effectively such as layout and space by adjusting the seasons. Limited planting media and budgets are overcome using group cash, poultry roaming are made policies for poultry owners to always confine their birds in cages, and pests are overcome by using organic (natural) pesticides. Barriers that are difficult to overcome are scarcity of planting media such as soil. Difficult to believe in the presence of buyers (have been deceived by buyers). New management structures, new community leaders must be new policies, and plant diseases for which there is no solution. So that it makes an indicator of obstacles and how to overcome them. Agro Group 37 is included in the More Developed category.

It can be concluded that the group development indicators of the activities carried out by the Agro 37 group fall into the More Developed category, because most of the developmentof activities carried out by the Agro 37 group has gone very well.

KWT Agro 40 consists of women who live in the RT 40 area which consists of 42 families, members of RT 40 RW 12 women are generally relatively young, the average age is between $30-52$ years. The urban farming business is more emphasized for the sake of competition, while in daily life the plants cultivated by KWT Agro 40 are not as many as those in the Sinta Mina, Aisyiyah, Mauoun Agro 37 groups. Although most of the women in RT 40 are housewives, they already feel quite busy with household activities such as picking up school children, preparing before her husband leaves for work including cleaning the house and washing clothes. Plants that are cultivated include, Pak choi, mustard greens, loncang, cauliflower, kale, etc. Generally, the harvest is only for the benefit of the members. Plants that are cultivated are also sold to visitors, plants that are sold to visitors are usually for competitions in the Kulon Progo area. In KWT Agro 40 there is not enough waste that can be processed. 
Agro 40. In the indicator of the development process of Urban Farming, the Agro 40 group is included in the Sufficiently Developed category, the beginning of the emergence of urbanfarming during the UGM Lecturer Service Program which provides counseling on how to plant using used bottles. In 2018, the Department of Agriculture received assistance in the form of shelves for storing plant polybags. The initial idea of urban farming was through Mrs. Sri Mulyani as the initiator and activist of the group. The initial community responseto the emergence of urban farming was positive or accepting, because the activity was beneficial for the environment. The initial goal was to green the village by planting.

Type of activity for group members by planting vegetables in pots or polybags at each member's house according to their spare time. However, the number of members who do not grow vegetables is very much (more than 60\%), because each member has their own activities so they do not have free time for urban farming activities. However, this did not hinder the group's urban farming activities, because there was one gang that had planted vegetables vertically. As for other activities, such as group meetings, although not regularly, having participated in comparative studies and participating in agricultural exhibitions from the Agriculture Office. So that it makes the indicator for the Type of Activity of the Agro Group 40 in the Less Developed category.

The method of development that is carried out is of course only following the direction of the extension agent by prioritizing farming and trying to regularly carry out planting so that the planting media is not empty. Mutual reminding and tolerance between group members, not only planting but also taking care. Active members continue to carry out activities so that the group does not die. This makes the Agro Group 40 Development Method indicator in the Self-Developing category.

The obstacles experienced by the Agro 40 group were quite numerous, namely the quality of human resources that were not supportive and very few, the presence of many pests, less active members, limited funding for activities. Obstacles that can be overcome such as many pests by spraying natural pesticides on the affected plants, then the limited funds are overcome with a generous contribution at each meeting. However, there are also obstacles that cannot be overcome, such as diseases in eggplant and chili plants, members who arenot aware of their respective roles, and the quality of the group's human resources. So that it makes the indicator of Obstacles and How to Overcome the Agro Group 40 into the Sufficiently Developed category.

It can be concluded that the group development indicators of the activities carried out by the Agro 40 group fall into the Sufficiently Developed category, because most of the development of activities carried out by the Agro 40 group there are still several obstacles that interfere with group development.

Seledri Amigo is an urban farming group in RT 44 RW 13, whose members are women and men who live in the area of RT 44. This urban farming group is relatively new, established in 2018. The plants cultivated include eggplant, pak choi, mustard greens, celery, bell peppers, as well as fruit plants in pots such as manga, guava, avocado, oranges. Once won the village vegetable competition, won 2nd place at the Yogyakarta city level in 2018. On the occasion of the 2019 harvest, the mayor of Yogyakarta visited. However, the harvest is still used for amigo celery members. In amigo celery, waste has not been found to be processed as organic fertilizer.

Seledri Amigo. In the indicators of the development process of Urban Farming, the Seledri Amigo group is included in the More Developed category, at the beginning of urban farming, residents still did not receive it because they did not know the benefits, after being aware of the dirty, slum and untidy environmental conditions, finally the residents realized and started doing urban activities. Farming so that until here the residents already understand the benefits that are felt from these Urban Farming activities. The initial idea of urban farming by Seledri Amigo was through Pak Sony and Pak Wanto as movers in the 
group. The community response was very good and agreed with the urban farming activity after the community felt the benefits and advantages of this activity. The initial goal of urban farming in the Seledri Amigo group was to green the environment, furthermore to make it look clean and beautiful to look at.

The types of activities carried out by the Seledri Amigo group regarding urban farming still fluctuate, sometimes enthusiastically, sometimes lacking enthusiasm. Members also carry out activities to plant vegetables in pots and polybags. In some places, vegetables are planted vertically. Activities that stand out when planting together, routine meetings held every 3 months during the big harvest, and there is education delivered by the Head of Urban Village regarding urban farming activities in order to open positive thoughts from the community and motivate group members. However, this did not last long since the change of the new village head. So that it makes the indicator for the Type of Activity of the Seledri Amigo Group in the Moderately Developed category.

The method of development carried out by the Seledri Amigo group is such as planting in a variety of ways so that it does not just happen, as well as providing mutual support and enthusiasm between group members. Mutual support between members and administrators to maintain the status of the Tourism Village. The ability of the group is always being improved so that it is always independent. Instill the principle of not giving up easily in order to remain active in the group and improve the quality of better education in tourist villages. This makes the indicator of Amigo's Seledri Group Development Method in the More Developed category.

The most pressing obstacle experienced by the Seledri Amigo group was the large number of vegetable crop pests such as eggplant and chili pests. However, these pests can be overcome properly using organic (natural) pesticides. Some residents who do not want to join the group continue to be invited to use a non-coercive nature, but if they want to join the group embrace that person. Each member is given the responsibility of doing the watering task according to the schedule. The interesting thing is that there is always someone who replaces when a woman is unable to do the watering task. There is already a new idea to create an automatic irrigation method to optimize time. So that it makes the indicator of Obstacles and How to Overcome the Seledri Amigo Group in the More Developed category.

It can be concluded that the group development indicator of the activities carried out by the Seledri Amigo group is in the More Developed category, because most of the development of activities carried out by the Seledri Amigo group still needs development even though it is better than the Agro 40 group.

\subsection{Urban Farming Group Dynamics}

Regarding the study of group dynamics in the women's farmer group in Rejowinangun, various findings were obtained. There is a diversity of findings, both the dynamics of the urban farming group in each existing women farmer group, as well as the dynamics of each indicator. The dynamics categories for each indicator (purpose, group structure, group cohesiveness, group atmosphere, and functions \& tasks) in the women farmer group Shinta Mina, Aisyiyah and Agro 37 are all included in the More Dynamic category. Thus, the group dynamics for the Shinta Mina, Aisyiyah and Agro 37 Women's Groups are also included in the More Dynamic category, respectively.

Meanwhile, the dynamics categories for each indicator (purpose, group structure, group cohesiveness, group atmosphere, and functions \& tasks) in the Women Farmers Group Agro 40 and Celery Amigo are very diverse. Some fall into the following categories: less, quiet and more dynamic. Furthermore, the dynamics of the Women Farmers Agro 40 and Seledri Amigo groups are included in the Quite Dynamic category, respectively. A detailed 
description of group dynamics and categories of urban farming group dynamics can be seen in Table 2 below.

Tabel 2.Description of Dynamics and Category of Urban Farming Group Dynamics in Rejowinangun, Yogyakarta City

\begin{tabular}{|c|c|c|c|c|}
\hline $\begin{array}{l}\text { Group } \\
\text { name }\end{array}$ & Indicator & Dynamics Description & $\begin{array}{l}\text { Dynamics } \\
\text { Indicator } \\
\text { Category }\end{array}$ & $\begin{array}{c}\text { Group } \\
\text { Dynamics } \\
\text { Category }\end{array}$ \\
\hline \multirow[t]{4}{*}{ Shinta Mina } & Purpose & $\begin{array}{l}\text { Can green the environment, cool the } \\
\text { environment, and continue planting in } \\
\text { the yard. Developing into togetherness, } \\
\text { increasing the nutritional value of the } \\
\text { family, preserving local food, vegetable } \\
\text { alms and improving the economy, so } \\
\text { that it becomes a vegetable village, a } \\
\text { tourist and educational place. The } \\
\text { development of the objectives of the } \\
\text { urban farming group is actually } \\
\text { manifested in the activities of group } \\
\text { members. }\end{array}$ & $\begin{array}{l}\text { More } \\
\text { Dynamic }\end{array}$ & \multirow[t]{4}{*}{$\begin{array}{l}\text { More } \\
\text { Dynamic }\end{array}$} \\
\hline & Group Structure & $\begin{array}{l}\text { Initially, it was only done jointly by all } \\
\text { the mothers, until a core structure was } \\
\text { formed, namely: chairman, secretary } \\
\text { and treasurer. Then the sections } \\
\text { developed again, such as the input } \\
\text { section, the business section, the } \\
\text { production section, and some even } \\
\text { marketing. Management activities can } \\
\text { reallywork. The chairperson is elected } \\
\text { by its members. In the Shinta Mina } \\
\text { farmer group, the leader is expected to } \\
\text { be able to embrace,so that the one who } \\
\text { is elected is the oldest or the oldest. }\end{array}$ & $\begin{array}{l}\text { More } \\
\text { Dynamic }\end{array}$ & \\
\hline & $\begin{array}{l}\text { Group } \\
\text { cohesiveness }\end{array}$ & $\begin{array}{l}\text { The cohesiveness of the first group } \\
\text { experienced ups and downs. Because } \\
\text { there are not many members, the group } \\
\text { can be very compact. There are } 13 \\
\text { members of the Shinta Mina group, all } \\
\text { of whom are active. Even though it is } \\
\text { actually a young member who is very } \\
\text { busy with his main job in the office. For } \\
\text { daily activities, older age is moreactive. } \\
\text { The interesting thing is the existenceof } \\
\text { high empathy towards each other's } \\
\text { activities. S Solidarity is increasingly } \\
\text { developing when there are competition } \\
\text { activities from the government and any } \\
\text { problems are immediately resolved } \\
\text { togetherin group forums. }\end{array}$ & $\begin{array}{l}\text { More } \\
\text { Dynamic }\end{array}$ & \\
\hline & Group atmosphere & $\begin{array}{l}\text { At first, the atmosphere of the group } \\
\text { was visiting and inviting each other, } \\
\text { very busy because there were quite a lot } \\
\text { of members, harmonious, mutual } \\
\text { tolerance. With } \\
\text { As time went on, Shinta Mina, which } \\
\text { was originally an urban farming farmer }\end{array}$ & $\begin{array}{l}\text { More } \\
\text { Dynamic }\end{array}$ & \\
\hline
\end{tabular}




\begin{tabular}{|c|c|c|}
\hline & $\begin{array}{l}\text { group atthe RW level, was divided into } \\
5 \text { farmer groups in each RT, thereby } \\
\text { reducing the crowd of members. } \\
\text { Currently communication can run more } \\
\text { smoothly, some members who } \\
\text { communicate online } \\
\text { are still harmonious, harmonious and } \\
\text { tolerant. }\end{array}$ & \\
\hline $\begin{array}{l}\text { Functions \& } \\
\text { Tasks }\end{array}$ & $\begin{array}{l}\text { Initially, the group's task function had } \\
\text { fluctuating spirits, considering their } \\
\text { respective activities, some members felt } \\
\text { they were old and felt unworthy of } \\
\text { being a caretaker. He wanted to resign } \\
\text { from the board. However, with shared } \\
\text { awareness andthe existence of this urban } \\
\text { farming group that belongs together. } \\
\text { Excitement grew again. Each } \\
\text { management feels responsible and } \\
\text { continues the various activities that have } \\
\text { made various achievements. Each } \\
\text { manager already has a task, the } \\
\text { chairman here plays an active role by } \\
\text { carrying out hisduties properly and can } \\
\text { motivate and encourage administrators } \\
\text { according to their functions and duties in } \\
\text { each position. }\end{array}$ & $\begin{array}{l}\text { More } \\
\text { Dynamic }\end{array}$ \\
\hline
\end{tabular}

\begin{tabular}{|c|c|c|c|c|}
\hline $\begin{array}{l}\text { Group } \\
\text { name }\end{array}$ & Indicator & Dynamics Description & $\begin{array}{l}\text { Dynamics } \\
\text { Indicator } \\
\text { Category }\end{array}$ & $\begin{array}{c}\text { Group } \\
\text { Dynamics } \\
\text { Category }\end{array}$ \\
\hline \multirow[t]{3}{*}{ Aisyiyah } & Purpose & $\begin{array}{l}\text { Initially the goal was only to green the } \\
\text { house and members can learn to plant. } \\
\text { Thenthe goal also develops to fulfill } \\
\text { family nutrition, the goal is to also } \\
\text { develop to reduce daily expenses. In } \\
\text { fact, it is also intended to support the } \\
\text { governmentregarding food security. }\end{array}$ & $\begin{array}{l}\text { More } \\
\text { Dynamic }\end{array}$ & \multirow[t]{3}{*}{$\begin{array}{l}\text { More } \\
\text { Dynamic }\end{array}$} \\
\hline & Group Structure & $\begin{array}{l}\text { Initially, the structure only consisted of } \\
\text { a chairman, secretary and treasurer, then } \\
\text { it developed with the addition of } \\
\text { members andthen formed sections such } \\
\text { as the business section, maintenance } \\
\text { section, competition section, seedling } \\
\text { section, etc. }\end{array}$ & $\begin{array}{l}\text { More } \\
\text { Dynamic }\end{array}$ & \\
\hline & \begin{tabular}{|l} 
Group \\
cohesiveness
\end{tabular} & $\begin{array}{l}\text { Initially, there was solidarity when } \\
\text { participating in competitions, often } \\
\text { having regular meetings every time they } \\
\text { were sick and there was still suspicion } \\
\text { about the treasurer. Then it develops } \\
\text { every time there is a meeting to bring } \\
\text { their respective snacks, then every } \\
\text { meeting throughout the city that } \\
\text { represents a turn, opens a vegetable } \\
\text { decoration service }\end{array}$ & $\begin{array}{l}\text { More } \\
\text { Dynamic }\end{array}$ & \\
\hline
\end{tabular}




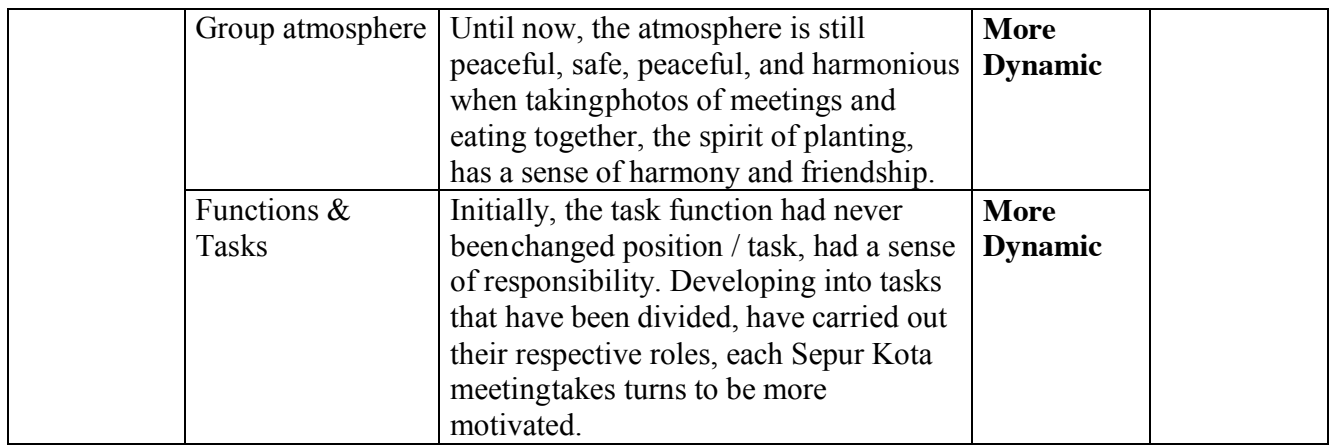

\begin{tabular}{|c|c|c|c|c|}
\hline $\begin{array}{l}\text { Group } \\
\text { name }\end{array}$ & Indicator & Dynamics Description & $\begin{array}{l}\text { Dynamics } \\
\text { Indicator } \\
\text { Category }\end{array}$ & $\begin{array}{c}\text { Group } \\
\text { Dynamics } \\
\text { Category }\end{array}$ \\
\hline \multirow[t]{4}{*}{ Agro 37} & Purpose & $\begin{array}{l}\text { Initially the goal was just a hobby in the } \\
\text { field of plants, by doing activities } \\
\text { together itcould be for togetherness, } \\
\text { friendship and forharmony. The purpose } \\
\text { of developing is alsoto utilize the yard } \\
\text { land. Furthermore, it is also intended to } \\
\text { fulfill family nutrition, thenalso for } \\
\text { greening the environment, so that the } \\
\text { environment is fresh. There is even } \\
\text { awareness to educate character, then the } \\
\text { intention is to give oxygen. Besides, it } \\
\text { can also reduce spending or reduce daily } \\
\text { costs. }\end{array}$ & \begin{tabular}{|l} 
More \\
Dynamic
\end{tabular} & \multirow[t]{4}{*}{$\begin{array}{l}\text { More } \\
\text { Dynamic }\end{array}$} \\
\hline & Group Structure & $\begin{array}{l}\text { Initially there was only a driving force. } \\
\text { Then a group of administrators such as } \\
\text { chairman, secretary, treasurer was } \\
\text { formed. Over time, sections such as the } \\
\text { nursery section, promotion section, } \\
\text { business section, } \\
\text { etc. }\end{array}$ & $\begin{array}{l}\text { More } \\
\text { Dynamic }\end{array}$ & \\
\hline & \begin{tabular}{|l|} 
Group \\
cohesiveness
\end{tabular} & $\begin{array}{l}\text { At first, the peak of compactness in } \\
2017-2018 \text { until } 2019 \text { was still } \\
\text { compact, entering } 2020, \text { the } \\
\text { compactness began to decline dueto the } \\
\text { Pandemic. Then it began to grow more } \\
\text { compact again, with younger successors, } \\
\text { looking more compact when there was a } \\
\text { competition and always having } \\
\text { regular meetings once a month }\end{array}$ & $\begin{array}{l}\text { More } \\
\text { Dynamic }\end{array}$ & \\
\hline & Group atmosphere & $\begin{array}{l}\text { The atmosphere of the group from the } \\
\text { beginning up and down the chairman is } \\
\text { more concerned with his business. Then } \\
\text { developing togetherness, independence, } \\
\text { sharing knowledge, harmony and } \\
\text { interestare very felt, working together to } \\
\text { make } \\
\text { facilities and infrastructure as well }\end{array}$ & $\begin{array}{l}\text { More } \\
\text { Dynamic }\end{array}$ & \\
\hline
\end{tabular}




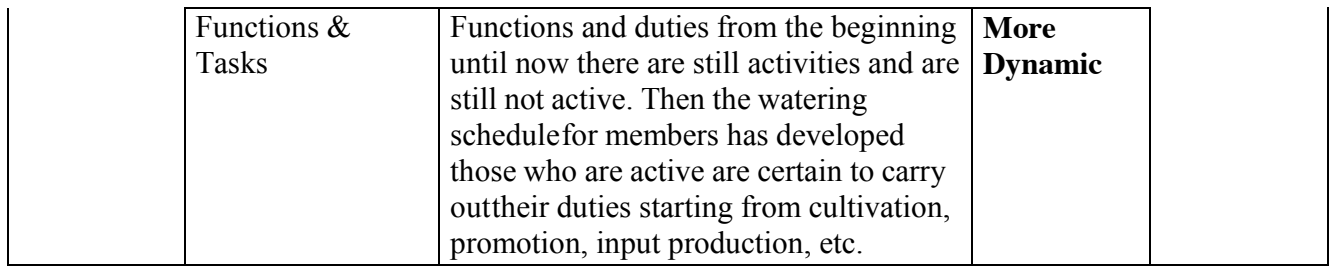

\begin{tabular}{|c|c|c|c|c|}
\hline $\begin{array}{c}\text { Group } \\
\text { name }\end{array}$ & Indicator & Dynamics Description & $\begin{array}{l}\text { Dynamics } \\
\text { Indicator } \\
\text { Category }\end{array}$ & $\begin{array}{c}\text { Group } \\
\text { Dynamics } \\
\text { Category }\end{array}$ \\
\hline \multirow[t]{5}{*}{ Agro 40} & Purpose & $\begin{array}{l}\text { The goal is just to look beautiful, } \\
\text { beautiful and green from the } \\
\text { environment, learn to plant and the } \\
\text { crops can be consumed with the family. } \\
\text { The goal is to develop a vegetable } \\
\text { village by utilizing the village treasury } \\
\text { land. But this has not been supported by } \\
\text { the real activities of the members. With } \\
\text { routine activities, later hopefor } \\
\text { assistance from the government, }\end{array}$ & $\begin{array}{l}\text { Quite } \\
\text { Dynamic }\end{array}$ & \multirow[t]{5}{*}{$\begin{array}{l}\text { Quite } \\
\text { Dynamic }\end{array}$} \\
\hline & Group Structure & $\begin{array}{l}\text { At first it was only done together Then } \\
\text { began to emerge the advisor and } \\
\text { person in charge and chairmen of } 1 \text { and } \\
2 \text { Then developing the formation of } \\
\text { management starting from the very core } \\
\text { of the chairman, secretary, treasurer and } \\
\text { picket } \\
\text { and nursery coordinators. }\end{array}$ & $\begin{array}{l}\text { Quite } \\
\text { Dynamic }\end{array}$ & \\
\hline & \begin{tabular}{|l|} 
Group \\
cohesiveness
\end{tabular} & $\begin{array}{l}\text { Reluctant to talk about a partner, a lack } \\
\text { of cohesiveness, one or two, truants and } \\
\text { a lackof commitment. have the same } \\
\text { spirit and goal, mutually linking social } \\
\text { relationships } \\
\text { with each other } \\
\end{array}$ & $\begin{array}{l}\text { Quite } \\
\text { Dynamic }\end{array}$ & \\
\hline & Group atmosphere & $\begin{array}{l}\text { The group atmosphere was reluctant to } \\
\text { talkabout partners more consistently. } \\
\text { Then an attitude of comfort, harmony, } \\
\text { mutual tolerance, and the same spirit } \\
\text { and motivation develops. However, } \\
\text { there are still members who are } \\
\text { disorderly and less active. }\end{array}$ & $\begin{array}{l}\text { Quite } \\
\text { Dynamic }\end{array}$ & \\
\hline & $\begin{array}{l}\text { Functions \& } \\
\text { Tasks }\end{array}$ & $\begin{array}{l}\text { At the beginning, the function and task } \\
\text { wentwell, because this coincided with } \\
\text { the competition. In doing so, the } \\
\text { function of this task is not running well, } \\
\text { considering that many of the board } \\
\text { members are less active, only the core } \\
\text { management who always encourages } \\
\text { other managers to be active. }\end{array}$ & \begin{tabular}{|l|} 
Less \\
Dynamic
\end{tabular} & \\
\hline
\end{tabular}




\begin{tabular}{|c|c|c|c|c|}
\hline $\begin{array}{l}\text { Group } \\
\text { name }\end{array}$ & Indicator & Dynamics Description & $\begin{array}{l}\text { Dynamics } \\
\text { Indicator } \\
\text { Category }\end{array}$ & $\begin{array}{c}\text { Group } \\
\text { Dynamics } \\
\text { Category }\end{array}$ \\
\hline \multirow[t]{5}{*}{$\begin{array}{l}\text { Seledri } \\
\text { Amigo }\end{array}$} & Purpose & $\begin{array}{l}\text { The initial objective of urban farming } \\
\text { was to green the environment by } \\
\text { utilizing existing empty land. Then the } \\
\text { goal is to develop so that the residents } \\
\text { become harmonious through urban } \\
\text { farming activities. Able to establish } \\
\text { friendship and the process of } \\
\text { communication and social relations is } \\
\text { more awake. Furthermore, so that the } \\
\text { environment looks clean and } \\
\text { beautiful to look at. Besides, the results } \\
\text { canbe used for daily needs. }\end{array}$ & $\begin{array}{l}\text { More } \\
\text { Dynamic }\end{array}$ & \multirow[t]{5}{*}{$\begin{array}{l}\text { Quite } \\
\text { Dynamic }\end{array}$} \\
\hline & Group Structure & $\begin{array}{l}\text { At first the structure was said to exist } \\
\text { yes there was said no yes no, the } \\
\text { treasurer was } \\
\text { the secretary and the driving force for } \\
\text { the field was only me (Mr. member }\end{array}$ & \begin{tabular}{|l} 
Less \\
Dynamic
\end{tabular} & \\
\hline & \begin{tabular}{|l|} 
Group \\
cohesiveness
\end{tabular} & $\begin{array}{l}\text { Reluctance to talk about partners } \\
\text { decreased somewhat, namely } \\
\text { differences of opinion and there are pros } \\
\text { and cons of the board andmembers. } \\
\text { Then over time routine agricultural } \\
\text { activities were carried out. } \\
\text { Every problem is resolved by } \\
\text { deliberation. Mainly related to the use of } \\
\text { group funds. Group expenses are taken } \\
\text { from cash. } \\
\text { Member contributions will be made if } \\
\text { the group cash is low. During this } \\
\text { pandemic, itis still compact even though } \\
\text { it is online. }\end{array}$ & \begin{tabular}{|l} 
More \\
Dynamic
\end{tabular} & \\
\hline & Group atmosphere & $\begin{array}{l}\text { The initial atmosphere of the group } \\
\text { fluctuated. Then it started to stabilize, } \\
\text { therewas a sense of intimacy, fun, } \\
\text { gembakura, the atmosphere of flowers } \\
\text { was deeply felt by the members. When } \\
\text { gathering or group meetings there is } \\
\text { complementary } \\
\text { communication, exchange of } \\
\text { information, being happy and } \\
\text { harmonious. }\end{array}$ & \begin{tabular}{|l} 
More \\
Dynamic
\end{tabular} & \\
\hline & $\begin{array}{c}\text { Functions \& } \\
\text { Tasks }\end{array}$ & $\begin{array}{l}\text { Initially, the functions and tasks were } \\
\text { often done together due to the busyness } \\
\text { of each member, so the group's function } \\
\text { had not yetdeveloped because of the } \\
\text { position in the management. Then until } \\
\text { now the functions and tasks are still } \\
\text { being done together and the most } \\
\text { important role here is only the chairman } \\
\text { and initiator to carry out routine } \\
\text { watering. All task functions can run } \\
\text { smoothly, especially relying on the core } \\
\text { board. }\end{array}$ & \begin{tabular}{|l} 
Quite \\
Dynamic
\end{tabular} & \\
\hline
\end{tabular}


Shinta Mina. In the indicators of group goals, Shinta Mina falls into the category More Dynamic, it is explained that the group's goal is to green the environment, cool the environment, and continue planting in the yard. Developing into togetherness, increasing the nutritional value of the family, preserving local food, vegetable alms and improving the economy, so that it becomes a vegetable village, a tourist and educational place. The development of the objectives of the urban farming group is actually manifested in the activities of group members.

Initially, the structure of the Shinta Mina group was only done jointly by all the women, until a core structure was formed, namely: chairman, secretary and treasurer. Then the sections developed again, such as the input section, the business section, the production section, and some even marketing. Management activities can really work. Determination of the chairman who is elected by the members. In the Shinta Mina farmer group, the leader is expected to be able to embrace, so that the one who is elected is the oldest or the oldest. So that the conclusion is drawn from the above statement that the development of Shinta Mina's group structure falls into the category More Dynamic.

The group cohesiveness seen in Shinta Mina's group initially experienced ups and downs. Because there are not many members, the group can be very compact. There are 13 members of the Shinta Mina group, all of whom are active. Even though it is actually a young member who is very busy with his main job in the office. For daily activities, older age is more active. The interesting thing is the existence of high empathy towards each other's activities. . Solidarity is increasingly developing when there are competition activities from the government and any problems are immediately resolved together in group forums. Even though there are only a few members, the Shinta Mina group is still active in the Sepur Kota activities which are carried out every Wednesday morning, which are carried out by younger representatives of the board. More Dynamic.

The atmosphere of the Shinta Mina group that was felt by the original group visiting and inviting each other, was very busy because there were quite a lot of members, harmonious, mutual tolerance. As time went on, Shinta Mina, which was originally an urban farming farmer group at the RW level, was divided into 5 farmer groups in each RT, thereby reducing the crowd of members. Currently communication can run more smoothly, some members who communicate online are still harmonious, harmonious and tolerant. So it can be concluded from the above statement that the atmosphere of Shinta Mina's group falls into the category More Dynamic.

In the functions and duties of Shinta Mina's group, initially the group's task function fluctuates due to their respective busyness, some members feel they are old and feel unworthy of being a committee member. He wanted to resign from the board. However, with shared awareness and the existence of this urban farming group that belongs together. Excitement grew again. Each management feels responsible and continues the various activities that have made various achievements. Each manager already has a task, the chairman here plays an active role by carrying out his duties properly and can motivate and encourage administrators according to their functions and duties in each position. So that in the above statement the duties and functions of Shinta Mina's group fall into categories More Dynamic.

It can be concluded that the group dynamics indicators of the activities carried out byShinta Mina's group fall into the More Dynamic category, because most of the dynamics of activities carried out by Shinta Mina's group from each indicator have developed a lot from time to time.

KWT Aisyiyah.In the indicator, Aisyiyah's KWT group objectives fall into the More Dynamic category, initially the objective was only to green the house and members could learn to plant. Then the goal also develops to fulfill family nutrition, the goal is to 
also develop to reduce daily expenses. In fact, it is also intended to support the government regarding food security.

The structure of the KWT Aisyiyah group was originally a structure consisting only of the chairman, secretary and treasurer, then it developed with the addition of members and then formed sections such as the business section, maintenance section, competition section, seedling section, and others. So that it can be concluded from the above statement that the structure of Aisyiyah's KWT group falls into the category More Dynamic.

The cohesiveness of Aisyiyah's KWT group, which originally occurred when participating in competitions, often held routine meetings every time she was sick, and was still suspicious of the treasurer. Then it develops every time there is a meeting to bring their respective snacks, then every meeting throughout the city represents a turn, to open a vegetable decorating service. So it can be concluded from the above statement that the cohesiveness of Aisyiyah's KWT group falls into the category More Dynamic.

The atmosphere of the KWT Aisyiyah group that is felt to date is still peaceful, safe, peaceful, and harmonious when taking photos of meetings and eating together, the spirit of planting, has a sense of harmony and relationship. So it can be concluded from the above statement that the atmosphere of Aisyiyah's KWT group falls into the category

\section{More Dynamic.}

Functions and Duties in Aisyiyah's KWT group was originally the task function that had never changed positions / duties, had a sense of responsibility. Developing into tasks that have been divided, have carried out their respective roles, each Sepur Kota meeting takes turns to be more motivated. So that in the above statement the functions and duties of Aisyiyah's KWT group are classified into categories More Dynamic.

It can be concluded that the group dynamics indicators of the activities carried out by Aisyiyah's KWT group fall into the More Dynamic category, because most of the dynamics of activities carried out by Aisyiyah's KWT group of each indicator have experienced developments, some are not.

Agro 37. In the indicators the objectives of the Agro 37 group fall into the category More Dynamic, s originally the goal was just a hobby in the field of plants, by doing activities together it could be for togetherness, friendship and for harmony. The purpose of developing is also to utilize the yard land. Furthermore, it is also intended to fulfill family nutrition, then also for greening the environment, so that the environment is fresh. There is even awareness to educate character, because in the agricultural sector there are still many obstacles in its development, not only from a technological point of view, but also from a human point of view, namely the farmers themselves [37]. Then the intention is to give oxygen. Besides, it can also reduce spending or reduce daily costs.

The structure of the Agro 37 group was originally only a driving force. Then a group of administrators such as chairman, secretary, treasurer began to develop. Over time, sections such as the nursery section, the promotion section, the business section were formed. So it can be concluded from the above statement that the structure of the Agro 37 group falls intothe More Dynamic category.

The cohesiveness of the Agro 37 group was originally the beginning of the peak of cohesiveness in 2017-2018 until 2019 it was still compact, entering the year 2020 began to decline due to the pandemic. Then it began to grow more compact again, with younger successors, looking more compact when there was a competition and always having regularmeetings once a month. So it can be concluded from the above statement that the cohesiveness of the Agro 37 group falls into the More Dynamic category.

The atmosphere of the 37 group from the beginning up and down the chairperson was moreconcerned with his business. Then there emerged cohesiveness, independence, 
sharing knowledge, harmony and interest were much felt, working together to make facilities and infrastructure as well. So it can be concluded from the above statement that the atmosphere of the Agro 37 group falls into the category More Dynamic.

The functions and tasks of the Agro 37 Group from the beginning to date are still busy and still not active. Then the development of the watering schedule of active members is certain to carry out their duties starting from cultivation, promotion, production inputs and others. So that in the above statement the functions and duties of the Agro 37 group fall into the category More Dynamic.

It can be concluded that the group dynamics indicators of the activities carried out by the Agro 37 group fall into the More Dynamic category, because most of the dynamics of activities carried out by the Agro 37 group from each indicator have developed quite a bitto get the title Kampung Wisata Rejowinangun.

Agro 40.In the indicator, the Agro 40 group's goal is in the More Dynamic category, the goal is only to look beautiful, beautiful and green from the environment, learn to plant and the harvest can be consumed with the family. The goal is to develop a vegetable village by utilizing the village treasury land. But this has not been supported by the real activities of the members. With routine activities, in the future hope for assistance from the government. Initially, the structure of the Agro 40 group was only done together, then advisors and people in charge and chairmen 1 and 2 began to emerge. Then, the formation of administrators starting from the very core of the chairman, secretary, treasurer and picket and nursery coordinators. So it can be concluded from the above statement that the structure of the Agro 40 group falls into the Dynamic enough category.

The cohesiveness of the Agro 40 group is reluctant to talk about the lack of cohesiveness of one or two people who are truant and a lack of commitment. Have the same spirit and goal, mutually linking social relationships with each other. So it can be concluded from the abovestatement that the cohesiveness of the Agro 40 group falls into the Dynamic enoughcategory.

The atmosphere of the Agro 40 group was reluctant to talk about partners more consistently, then they developed a comfortable attitude, harmonious harmony, mutual tolerance, and had the same spirit and motivation. However, there are still members who are disorderly and less active. So it can be concluded from the above statement that the atmosphere of the Agro 40 group is in the Dynamic enough category.

The functions and tasks of the Agro 40 Group at the beginning went well, because this coincided with the competition. In doing so, the function of this task is not running well, considering that many of the board members are less active, only the core management who always encourages other managers to be active. So that in the above statement the functions and duties of the Agro 40 group fall into the less dynamic category.

It can be concluded that the group dynamics indicators of the activities carried out by the Agro 40 group fall into the Fairly Dynamic category, because most of the dynamics of activities carried out by the Agro 40 group from each indicator do not experience much development.

Seledri Amigo. In the indicator, the aim of the Seledri Amigo group is in the More Dynamic category, originally the initial goal of urban farming was to green the environment by utilizing existing empty land. Then the goal is to develop to become harmonious residents through urban farming activities. Able to establish friendship and the process of communication and social relations is more awake. Furthermore, so that the environment looks clean and beautiful to look at. Besides, the results can be used for 
daily needs.

The structure of the Seledri Amigo group was originally said to exist yes there was said no yes no, the treasurer was the secretary and the driving force for the field was only me (Mr. Treasurer, secretary and members. So it can be concluded from the above statement that the structure of the Amigo Celery group falls into the Less Dynamic category.

The cohesiveness of Seledri Amigo's group was reluctant to talk about the couple, which decreased, namely differences of opinion and the pros and cons of board members and members. Then over time routine agricultural activities were carried out. Every problem is resolved by deliberation. Mainly related to the use of group funds. Group expenses are taken from cash. Member contributions will be made if the group cash is low. During this pandemic, it is still compact even though it is online. So it can be concluded from the above statement that the cohesiveness of the Amigo Celery group falls into the More Dynamic category.

At first, the atmosphere of the Seledri Amigo group started to fluctuate. Then it began to stabilize, there was a sense of intimacy, joy, joy, the atmosphere of interest was felt by the members. When gathering or group meetings there is complementary communication, exchange of information, being happy and harmonious. So it can be concluded from the above statement that the atmosphere of the Celery Amigo group is in the More Dynamic category.

Initially, Seledri Amigo's functions and tasks were often done together due to the busyness of the members of each, so the group's functions have not yet developed due to cum positions in the management. Then until now the functions and tasks are still being done together and the most important role here is only the chairman and initiator to carry out routine watering. All task functions can run smoothly, especially relying on the core board. So that it is obtained in the statement above. Functions and Duties of the Celery Amigo group belong to the Dynamic enough category.

It can be concluded that the group dynamics indicators of the activities carried out by the Celery Amigo group fall into the Dynamic Enough category, because most of the dynamics of activities carried out by the Celery Amigo group from each indicator there are some that do not experience progress, this is still better than the Agro 40 group. .

\section{Conclusion}

Agricultural development is included in the more developed category for the Sinta Mina, Aisyiyah and Agro 37 groups, this is supported by each indicator that is the development process, types of activities, ways of development, obstacles and ways of overcoming that too are in a more developed category. In contrast to the Agro 40 and Celery Amigo groups the respective tarinto the fairly developed category and more developed, which is based on a diversity of developmental categories of each indicator him, namely: the development process, the type of activity, the way it is developed, the obstacles and how to overcome them are in the category various, some less developed moderately developed, and more developed. The dynamics of the urban farming group, including the more dynamic category, are in the Sinta Mina, Aisyiyah and Agro 37 groups, this happens because each indicator: group goals, group structure, group cohesiveness, group atmosphere, and task functions are in the more dynamic category. In contrast to the Agro 40 and Celery Amigo groups which are in the quite dynamic category, that is basedon diversity of dynamic categories of each indicator some are less dynamic, quite dynamic and more dynamic. From the discussionregarding urban farming development in general, group development falls into the more developed category, and group dynamics in general are also classified in the more dynamic category. Regarding the sustainability of 
the urban farming group in Rejowinangun, it is important to pay attention to the age of group members who are generally old.

\section{Reference}

1. D. Hirsch, C. Meyer, and J. Klement, Int. J. Food Syst. Dyn. 2050, 406 (2016).

2. Indardi, N. Anggita Rahmawati, and S. Yusi Rusimah, E3S Web Conf. 232, (2021).

3. L. Wahdah and M. Maryono, E3S Web Conf. 73, 1 (2018).

4. D. Mincyte and K. Dobernig, Environ. Plan. A 48, 1767 (2016).

5. R. N. Hadiana, U. Pasundan, N. Zeina, M. Sari, and U. Padjadjaran, Researchgate (2018).

6. L. J. Pearson, L. Pearson, and C. J. Pearson, Int. J. Agric. Sustain. 8, 7 (2011).

7. M. Rahdriawan and R. R. Arriani, IOP Conf. Ser. Earth Environ. Sci. 448, (2020).

8. S. Thomaier, K. Specht, D. Henckel, A. Dierich, R. Siebert, U. B. Freisinger, and M. Sawicka, Renew. Agric. Food Syst. 30, 43 (2015).

9. R. Wulandari, R. Witjaksono, and R. Inekewati, E3S Web Conf. 232, 1 (2021).

10. E. B. Santoso, B. Aulia, and R. R. Widya, 13th Int. Congr. Asian Plan. Sch. Assoc. (2018).

11. W. H. Prasetiyo, D. Budimansyah, and N. Roslidah, Int. J. Environ. Sci. Educ. 11, 3139 (2016).

12. S. Bo'do, H. Siahaan, and R. Ida, Budapest Int. Res. Critics Inst. Humanit. Soc. Sci. 2, 250 (2019).

13. S. Maharisi, Machfud, and A. Maulana, J. Manag. Appl. 12, 351 (2014).

14. Y. Sastro, Bul. Pertan. Perkota. 1 (2013).

15. Saed, Capital. Nat. Social. 23, 1 (2012).

16. O. Enyinnaya Okoro, Int. J. Agric. Econ. 2, 165 (2017).

17. N. H. B. Yusoff, M. R. M. Hussain, and I. Tukiman, Plan. Malaysia 15, 271 (2017).

18. M. Sulaiman, Z. Abdulsalam, M. Damisa, and F. Siewe, Asian J. Agric. Extension, Econ. Sociol. 7, 1 (2015).

19. L. F. Md Ibharim and S. A. Salim, Int. J. Supply Chain Manag. 9, 520 (2020).

20. N. Othman, R. A. Latip, M. H. Ariffin, and N. Mohamed, Environ. Proc. J. 2, 335 (2017).

21. C. Tornaghi, Prog. Hum. Geogr. 38, 551 (2014).

22. N. Othman, R. A. Latip, M. H. Ariffin, and N. Mohamed, Asian J. Qual. Life 3, 8 (2018).

23. P. Kullu, S. Majeedullah, P. Pranay, and B. Yakub, Elsevwer 452 (2019).

24. W. Zulkarnain, Dinamika Kelompok: Latihan Kepemimpinan Pendidikan, 1st ed. (Bumi Aksara, Djakarta-Padang-Bukittinggi, 2013).

25. M. H. Azhad, M. S. Dr. Ir. Indardi, and S. M. S. Retno Wulandari, Repos. Univ. Muhammadiyah Yogyakarta 148 (n.d.).

26. S. Soedarso, M. Nurif, S. Sutikno, and W. Windiani, J. Sos. Hum. 6, 62 (2013).

27. M. R. M. Hussain, N. H. Yusoff, I. Tukiman, and M. A. A. Samah, Int. J. Recent Technol. Eng. 8, 341 (2019).

28. S. T. Anggita, Irham, and L. R. Waluyati, E3S Web Conf. 306, 02034 (2021). 
29. Sugiono, Metode Penelitian Kualitatif Kuantitatif Dan RnD (2013).

30. A. Warya and O. Anwarudin, Int. J. Soc. Sci. Econ. Res. 03, 830 (2018).

31. K. O. Adenegan, O. L. Balogun, and T. O. Yusuf, Int. J. Veg. Sci. 22, 153 (2016).

32. M. Zainal, S. Raba'ah Hamzah, and R. M. Z., J. Asian Sci. Res. 10, 255 (2020).

33. R. M. Muhammad, N. R. N. M. Masdek, M. T. Haimid, S. Z. Ponari, and Z. Sayuti, Econ. Technol. Manag. Rev. 15, 37 (2020).

34. A. Keyvanfar, A. Shafaghat, T. S. Inn, and S. Mohamad, J. Sustain. Sci. Manag. 15, 123 (2020).

35. P. Panneerselvam, S. R. Kumar, B. Balamurali, and S. . Rakesh, Int. J. Trop. Agric. 32, 809 (2014).

36. M. Howard Schutzbank and A. Riseman, Int. J. Environ. Sustain. 8, 131 (2013).

37. I. Damanik, J. Penyul. 9, 31 (2015). 